\title{
Sociedade regulada e radicalismo democrático: princípios gramscianos para conformação do projeto ético-político profissional do Serviço Social
}

\author{
Douglas Ribeiro Barboza \\ Universidade Federal Fluminense (UFF)
}

\author{
Jacqueline Aline Botelho Lima Barboza \\ Universidade Federal Fluminense (UFF)
}

\begin{abstract}
Sociedade regulada e radicalismo democrático: princípios gramscianos para conformação do projeto ético-político profissional do Serviço Social

Resumo: Este artigo busca resgatar a questão do radicalismo democrático na teoria de Gramsci, o qual afirma a necessidade de instauração de uma sociedade auto regulada em que a divisão entre governantes e governados será eliminada e as classes subalternas serão elevadas à condição de protagonistas, dirigentes e responsáveis da sua própria história. As formulações gramscianas contribuem para refletir sobre as possibilidades de consolidação e avanço da direção estratégica do atualmente hegemônico projeto ético-político do Serviço Social.

Palavras-chave: Gramsci. Democracia. Sociedade regulada. Projeto ético-político.
\end{abstract}

Regulated Society and Democratic Radicalism: Gramscian principles for the conformation of a professional ethical-political project for Social Service

Abstract: This article reviews the issue of democratic radicalism in Gramscian theory, which affirms the need to establish a selfregulated society in which the division between the governed and the government would be eliminated and the subaltern classes would be raised to the condition of protagonists and leaders and become responsible for their own history. The Gramscian formulations contribute to a reflection on the possibilities for consolidation and advance of the strategic direction of the currently hegemonic ethicalpolitical project of social service.

Keywords: Gramsci. Democracy. Regulated society. Ethical-political Project. 


\section{Introdução}

Nascida no seio dos projetos burgueses conservadores, o processo de institucionalização da profissão vincula-se com o processo de desenvolvimento da democracia política ${ }^{1}$ no período monopolista: as exigências democráticas efetuadas através da pressão dos trabalhadores, via organização sindical e partidária, em face do movimento de concentração e centralização do capital, obriga o Estado burguês a não mais encaminhar a sua intervenção de modo repressivo, mas sim dimensionar a sua ação integradora-coesiva de forma a assimilá-la às exigências da ordem monopolista. A consolidação dos direitos políticos e a constituição dos direitos sociais coroaram, na concepção marshalliana, a cidadania moderna na sua tríplice dimensão, civil, política e social, exigindo do Estado burguês uma reciclagem no tratamento da questão social e a subsequente instauração das políticas sociais, a partir da qual se abriu o campo profissional em que o Serviço Social adquiriu a sua face contemporânea, e cuja direção do seu projeto profissional conformou-se como uma resposta burguesa às possibilidades anticapitalistas contidas na democracia política. $\mathrm{O}$ atualmente hegemônico projeto ético-político profissional do Serviço Social brasileiro é resultante de um processo de lutas pela democratização, que se caracterizou como o substrato sócio histórico para que o rompimento com o tradicionalismo profissional e seu caráter conservador engendrasse uma cultura profissional bastante diversa, impulsionadora de um redimensionamento e uma renovação da profissão no quadro da sua interpretação teórico-metodológica e política. Sua direção social estratégica posiciona-se a favor da equidade e da justiça social, e opta "por um projeto profissional vinculado ao processo de construção de uma nova ordem societária, sem dominaçãoexploração de classe, etnia e gênero", no qual a "defesa do aprofundamento da democracia, enquanto socialização da participação política e da riqueza socialmente produzida" se constituiu como um dos seus princípios fundamentais (CRESS, 2008, p. 37).

Considerando que o Serviço Social, no tocante à sua institucionalização, ao seu desenvolvimento e, especialmente, às suas atuais perspectivas, mantém uma inerente articulação com a problemática do Estado e da democracia e que cuja direção do seu projeto profissional conformou-se como uma resposta burguesa às possibilidades anticapitalistas contidas na democracia, o presente artigo busca resgatar como a questão da democracia e do Estado perpassa o esforço de reconstrução do campo teórico do marxismo efetuado por Gramsci, reconstrução desenvolvida como resposta à crise aberta do marxismo após a desestruturação da Segunda Internacional e ao fracasso da estratégia da Terceira Internacional. Resgata a afirmação radicalmente democrática gramsciana de que a divisão entre governantes e governados, entre dirigentes e dirigidos não é uma divisão perpétua do gênero humano, mas sim apenas um fato histórico, correspondente a certas condições, o que impulsiona a necessidade de lutar para que seja alcançada a criação de condições nas quais seja eliminada a necessidade de existência desta divisão, até a instauração de uma sociedade auto regulada.

\section{O valor democrático da função educativa e formativa do Estado ético}

Gramsci $(2002,3$, p. 271) ressalta que, enquanto as classes dominantes pré-capitalistas possuíam um caráter essencialmente conservador ${ }^{2}$ e permaneceram fechadas na sua concepção de casta, a classe burguesa pôs-se a si mesma "como um organismo em contínuo movimento, capaz de absorver toda a sociedade, assimilando-a a seu nível cultural e econômico", transformando toda a função do Estado e tornando-o "educador". Com a complexificação do exercício da hegemonia no período pós Primeira Guerra Mundial, a classe burguesa, que na sua marcha traz consigo um novo tipo de Estado, cada vez mais complexo e baseado na organização do consenso, se vê saturada: "não só não se difunde, mas se desagrega; não só não assimila novos elementos, mas desassimila uma parte de si mesma (ou, pelo menos, as dissimilações são muitíssimo mais numerosas do que as assimilações)" (GRAMSCI, 2002, 3, p. 271), uma paralisação que acarreta num retorno à concepção do Estado como pura força. Esta crise de hegemonia, a separação da sociedade civil em relação à sociedade política, faz deslocar a base histórica do Estado: "tem-se uma forma extrema de sociedade política; ou para lutar contra o novo e conservar o que oscila, fortalecendo-o coercitivamente, ou como expressão do novo para esmagar as resistências que encontra ao desenvolver-se" (GRAMSCI, 2002, p. 263). Se algumas autonomias que foram abolidas pelo Estado moderno (a substituição do bloco mecânico dos grupos sociais por uma subordinação destes à hegemonia ativa do grupo dirigente e dominante) conseguem renascer sob novas formas (partidos, sindicatos, associações de cultura etc.), nas ditaduras contemporâneas até mesmo estas novas formas de autonomia são abolidas legalmente e são incorporadas à atividade estatal: "a centralização legal de toda a vida nacional nas mãos do grupo dominante se torna 'totalitária"' (GRAMSCI, 2002, p. 139).

De acordo com Liguori (2007, p. 34), certamente Gramsci está se referindo ao fascismo, mas não seria um disparate considerar que suas avaliações também deságuam no regime soviético, tendo em vista 
que sua reflexão é alimentada por contínuas referências às experiências históricas desses dois Estados que ele tinha diante de si como polos opostos, porém, por motivos diversos, ambos fortemente presentes: "o Estado fascista, que o aprisiona, e o Estado soviético, em cuja causa ele se reconhece". Por outro lado, não se pode desconsiderar que Gramsci, ainda que com limites devidos ao próprio tempo histórico em que vive e reflete, foi um dos pioneiros na compreensão de que, também nos Estados liberal-democráticos, "existem novos e importantes fenômenos de 'organização das massas', de regulamentação até mesmo forçada das suas modalidades de vida". Gramsci apontara que a revolução provocada pela classe burguesa na concepção do direito e, portanto, na função do Estado, consiste especialmente na vontade de conformismo, isto é, a eticidade do direito e do Estado. A questão do conformismo social é a tarefa educativa e formativa do Estado, cujo objetivo sempre se caracteriza pela criação de novos e mais elevados tipos de civilização e de cidadão e, portanto, de convivência e de relações individuais. Sua finalidade consiste em adequar a civilização e a moralidade das mais amplas massas populares "às necessidades do contínuo desenvolvimento do aparelho econômico de produção e, portanto, de elaborar também fisicamente tipos novos de humanidade" (GRAMSCI, 2002, p. 23). O Estado tende, assim, a fazer desaparecer certos costumes e atitudes e a difundir outros, finalidade esta na qual o direito, além da escola e de outras instituições, será o instrumento que deverá ser elaborado para tornar-se maximamente eficaz e produtor de resultados positivos. Neste quadro, o Estado deve ser concebido como educador, como Estado ético:

todo Estado é ético na medida em que uma de suas funções mais importantes é elevar a grande massa da população a um determinado nível cultural e moral, nível (ou tipo) que corresponde às necessidades de desenvolvimento das forças produtivas e, portanto, aos interesses das classes dominantes. A escola como função educativa positiva e os tribunais como função educativa repressiva e negativa são as atividades estatais mais importantes neste sentido: mas, na realidade, para este fim tende uma multiplicidade de outras iniciativas e atividades chamadas privadas, que formam o aparelho da hegemonia política e cultural das classes dominantes (GRAMSCI, 2002, p. 382).

Uma dessas iniciativas estreitamente ligada à hegemonia política, isto é, como ponto de contato entre a sociedade civil e a sociedade política, entre o consenso e a força, é a conformação do que se denomina como opinião pública: quando deseja iniciar uma ação pouco popular, o Estado, de forma preventiva, cria a opinião pública adequada, ou seja, "organiza e centraliza certos elementos da sociedade civil" (GRAMSCI, 2002, p. 265). Tendo em vista que a opinião pública é o conteúdo político da vontade política pública e que esta última, por sua vez, pode ser discordante, a sociedade civil está longe de se caracterizar como uma arena livre na qual os atores, através do diálogo e da ação comunicativa, criam o tecido conectivo da convivência democrática. Pelo contrário, é justamente por esta discordância que a sociedade civil se mantém sempre permeada por uma luta pela hegemonia, isto é, nela sempre existe luta pelo monopólio dos órgãos da opinião pública (jornais, partidos, Parlamento), "de modo que uma só força modele a opinião e, portanto, a vontade política nacional, desagregando os que discordam numa nuvem de poeira individual e inorgânica". Um exemplo dessa modelação se dá através da capacidade exercida pelos meios de comunicação de massa (na sua época, principalmente o rádio e a imprensa marrom) em efetuar, extemporaneamente, súbitas e fictícias "explosões de pânico ou entusiasmo", de forma a permitir o alcance de determinados objetivos numa eleição (GRAMSCI, 2002, 3, p. 270). Num sistema eletivo de formação dos órgãos estatais, uma das maiores e mais banais falácias consiste em considerar que o número é a lei suprema e que o peso das opiniões de cada eleitor, indistintivamente, é exatamente igual; pois se as ideias e as opiniões apresentadas na forma política de atualidade na verdade "não 'nascem' espontaneamente no cérebro de cada indivíduo", mas sim possuem "um centro de formação, de irradiação, de difusão, de persuasão", então os números se tornam "um simples valor instrumental", que dão apenas uma medida e uma relação da "eficácia e [da] capacidade de expansão e de persuasão de opiniões de poucos, das minorias ativas, das elites, das vanguardas etc., isto é, sua racionalidade ou historicidade ou funcionalidade concreta" (GRAMSCI, 2002, p. 82). Em outras palavras, o número de votos é a manifestação terminal de um longo processo no qual a maior influência pertence exatamente àquele pretenso grupo de excelências que dedica as infindáveis forças materiais que possui para a obtenção do consenso da maioria. O Estado, na sua tarefa educativa e formativa do conformismo social acaba por eliminar toda a espontaneidade possível à sociedade civil.

Cônscio das derrapagens totalitárias do Estado no século 20 e atento para precisar os perigos para o próprio movimento comunista, Gramsci (2002, 2, p. 230) afirma que o argumento da tarefa educativa e formativa do Estado só passa a ter um valor verdadeiramente democrático "nas sociedades em que a unidade histórica de sociedade civil e sociedade política for entendida dialeticamente (na dialética real e não conceitual)". No processo de luta por hegemonia que atravessa o terreno do Estado Integral, urge a necessidade de que as 
classes subalternas, que somente podem se unificar quando logram tornar-se Estado, consigam manter a sua própria autonomia e promover uma própria hegemonia que seja alternativa à dominante, antes que um prolongamento da estatolatria ${ }^{3}$ venha a tornar definitivo um governo que deveria ser provisório. A identificação entre indivíduos de um determinado grupo social e Estado deve ser uma identificação orgânica, dialética, de interpelação e influência recíproca, de maneira que a afirmação "todo indivíduo é funcionário" não seja referida ao fato de que este "é empregado pago pelo Estado e submetido ao controle "hierárquico' da burocracia estatal", mas sim porque, “'agindo espontaneamente', sua ação se identifica com os fins do Estado (ou seja, do grupo social determinado ou sociedade civil)" (GRAMSCI, 2002, p. 282). Essa identificação do Estado com os indivíduos de um grupo social, como elemento de cultura ativa, isto é, como movimento para criar uma nova civilização, deve servir para determinar a vontade de construir, no invólucro da sociedade política, uma complexa e bem articulada sociedade civil, na qual o indivíduo particular "se governe por si sem que, por isto, este seu autogoverno entre em conflito com a sociedade política, tornando-se, ao contrário, sua normal continuação, seu complemento orgânico" (GRAMSCI, 2002, p. 279).

Nas notas escritas entre 1931-1932, Gramsci (2002, p. 222) afirma que o valor democrático da função educativa e formativa do Estado só se realiza quando este Estado é concebido como capaz de ser superado pela sociedade regulada, a sociedade comunista, sociedade esta na qual o partido dominante não se confunde organicamente com o governo, uma vez que a atividade desse partido, voltada para a elevação das massas e das iniciativas políticas da sociedade civil, resulta no seu próprio desaparecimento:

Na realidade de qualquer Estado, o 'chefe de Estado', isto é, o elemento equilibrador dos diversos interesses em luta contra o interesse predominante, mas não exclusivista em sentido absoluto, é exatamente o "partido político"; ele, porém, ao contrário do que se verifica no direito constitucional tradicional, não reina nem governa juridicamente: tem 'o poder de fato'; exerce a função hegemônica (e, portanto, equilibradora de interesses diversos) na 'sociedade civil', mas de tal modo esta se entrelaça de fato com a sociedade política que todos os cidadãos sentem que ele reina e governa. Sobre esta realidade, que está em contínuo movimento, não se pode criar um direito constitucional do tipo tradicional, mas apenas um sistema de princípios que afirmam como finalidade do Estado seu próprio fim, seu próprio desaparecimento, isto é, a reabsorção da sociedade política na sociedade civil.

Percebe-se aqui a preocupação gramsciana sobre a necessidade da criação de condições nas quais seja eliminada a necessidade de existência da divisão entre governantes e governados, entre dirigentes e dirigidos, a qual deve ser considerada "apenas [como] um fato histórico, correspondente a certas condições" e não como "uma divisão perpétua do gênero humano" (GRAMSCI, 2002, p. 325). Conforme destaca Semeraro (2001, p. 94): "o projeto de socialização da produção e da política implica também a socialização do poder e o máximo desenvolvimento da subjetividade individual e social", revelando que a finalidade de toda a atividade política consiste em criar condições para a expansão da "sociedade civil" até o ponto em que esta possa se apropriar do poder separado da "sociedade política" e se transforme, assim, em sociedade regulada "organizada por sua própria autodeterminação, onde cada sujeito e a pluralidade de associações livremente constituídas passam a agir por convicção e por razões de ordem ética". Gramsci (2002, p. 230) afirma que o partido dominante, nesta sociedade, "não se confunde organicamente com o governo, mas é instrumento para a passagem da sociedade civil-política à sociedade regulada, na medida em que absorve ambas em si, para superá-las (e não para perpetuar sua contradição)", e chega a contrapor o "governo dos funcionários" (sociedade política) ao "autogoverno" (sociedade civil), isto é, a gestão burocrática do Estado sendo preterida pelo "autogoverno dos produtores", o qual se expressa por meio dos organismos da sociedade civil.

Gramsci retoma e concretiza nos Cadernos o problema sobre qual Marx, Engels e Lênin haviam se debruçado, isto é, a tarefa de encontrar uma forma de organização da sociedade que, ao superar todo antagonismo de classe, consiga eliminar o aparato de repressão, construído em vista da guerra de classes interna e do conflito armado com outras classes explorados concorrentes no nível internacional. Ao mesmo tempo, pode-se perceber como o marxista sardo supera dialeticamente seus antecessores ao supor que, para a extinção do Estado, é necessário um embate no âmbito específico da política e das instituições socialistas de forma que se possibilite o fim da alienação manifestada na existência de um Estado separado da sociedade, seja qual for conteúdo de classe desse Estado. A extinção do Estado como reabsorção da sociedade política na sociedade civil significa que o avanço na construção do socialismo incorre num desaparecimento progressivo dos mecanismos de coerção, ou seja, as funções sociais de domínio e coerção vão perdendo gradativamente espaço para as funções de hegemonia e consenso: "numa doutrina do Estado que conceba este como tendencialmente capaz de esgotamento e de dissolução na sociedade regulada", é de fundamental importância compreender que a distinção entre sociedade civil e sociedade política não é orgânica, mas sim metodológica (GRAMSCI, 
2002, p. 47), que "na noção geral de Estado entram elementos que devem ser remetidos à noção de sociedade civil (no sentido de que Estado = sociedade política + sociedade civil)" (GRAMSCI, 2002, p. 244). A sociedade civil também é Estado, aliás, é o próprio Estado.

É preciso questionar, então, sobre até que ponto esta reabsorção da sociedade política na sociedade civil comporta o advento de uma sociedade realmente sem Estado, já que a tese de sua extinção requer o errôneo abandono da compreensão de que sociedade civil e Estado, a sociedade política, se identificam na realidade dos fatos numa relação de unidade-distinção (GRAMSCI, 2002). Gramsci (2002, p. 244), ao destacar que o processo de esgotamento do elemento Estado-coerção se realiza "à medida que se afirmam elementos cada vez mais conspícuos de sociedade regulada (ou Estado Ético, ou sociedade civil)", concebe que tal forma de organização da sociedade comunista é ela própria uma forma de Estado, o que nos traz a necessidade de compreendermos melhor esta configuração do comunismo como sociedade regulada.

Marx e Engels já haviam definido como pré-história da humanidade aquela condição feita de violência e abuso, isto é, os restos do estado de Natureza enxergados por Hegel (1997) na sociedade burguesa de seu tempo, e apontavam a superação desta condição no comunismo que, para os fundadores do socialismo científico, representava o início da história da humanidade conciliada. É exatamente pela condição de superação do estado de natureza, do abuso e da violência próprias de uma sociedade fundada no domínio de classe e na polarização de pobreza e riqueza, que esse novo ciclo histórico qualitativo é concebido por Gramsci como o advento de uma sociedade regulada, onde cada um será capaz de obedecer às leis formuladas por ele mesmo, e não como o início de um período anárquico, no qual ocorreria o desaparecimento de todas as normas. Gramsci (2002, p. 245) afirma que o comunismo é a realização daquela imagem de Estado sem Estado, de Estado ético, que toma o lugar do Estado como organização da violência de classe, e que, nos maiores cientistas da política e do direito ${ }^{4}$, permaneceu no terreno da pura utopia, tendo em vista que prescinde das colossais mudanças materiais que lhe confere resistência e que lhe dá base. Ou seja, pressupõe da condição de que "todos os homens são realmente iguais e, portanto, igualmente razoáveis e morais, isto é, passíveis de aceitar a lei espontaneamente, livremente, e não por coerção, como coisa imposta por outra classe, como coisa externa à consciência". Enquanto a eticidade de Hegel supõe que os indivíduos isolados na sociedade civil só conseguem alcançar a plena realização de si mesmos através da universalização de suas relações, da adesão consciente a uma necessidade, sem considerar em momento algum a ordem da realidade existente assumida em sua totalidade (HEGEL, 1997), a concepção ético-política de Gramsci prevê que a realização das classes subalternas exige o conflito e a superação do capitalismo que as nega como seres humanos, através de uma reforma intelectual e moral cujos valores lançam os pilares da sociedade auto regulada e tornam supérflua a função do Estado, já que foram vencidas as relações opressivas de poder. Sendo assim, quando Gramsci aponta a dissolução do Estado, não está postulando uma sociedade sem Estado, mas sim a superação do Estado capitalista, portador de violência e abuso, de guerras e divisões; refere-se, na realidade, a uma nova sociedade que cria um novo tipo de Estado, onde se extingue os mecanismos do Estado-coerção, da sociedade política, e mantém-se preservado os organismos da sociedade civil, os quais se convertem nos portadores materiais do autogoverno dos produtores associados (COUTINHO, 1999). A instauração da sociedade regulada não significa, para Gramsci, a concretização de uma sociedade sem governo, a eliminação de qualquer estrutura política e social, mas sim a criação de outra organização social mais forte e complexa, gestada na formação da vontade coletiva 5 .

\section{A crítica gramsciana aos mecanismos da democracia moderna}

Neste quadro, qual seria a posição de Gramsci com relação aos mecanismos da democracia moderna? Para o marxista sardo, a democracia moderna se apresentava mais como uma expressão do declínio da velha ordem social do que o início da "nova civilização" (BADALONI, 1975, p.128), e o sistema político-parlamentar burguês, além de natureza puramente formal e burocrática, favorecia qualquer intenção de manipulação e falsificava a relação dialética de representação, que deveria estar subjacente ao movimento de adesão orgânica e troca de elementos individuais entre dirigentes e dirigidos, governantes e governados, intelectuais e povonação - isto é, a realização da vida em conjunto, "a única que é força social." (GRAMSCI, 2002, 3, p. 222).

Pode-se dizer, todavia, que a postura gramsciana com relação aos mecanismos da democracia parlamentar contrabalança-se, de forma muito sutil, entre a crítica e uma aceitação provisória. Como, por exemplo, nas suas análises acerca das eleições gerais e plebiscitos como "momentos de vida intensamente coletiva e unitária no desenvolvimento nacional do povo italiano", mas que, em certos momentos, carregavam em si a difusão de uma "convicção mística de que tudo mudaria após o voto, a convicção de uma verdadeira regeneração social" (GRAMSCI, 2002, p. 56-58). 
Outro exemplo emblemático deste posicionamento gramsciano refere-se à crítica a uma direta identificação entre conquista do consenso das massas e busca do sucesso eleitoral. Gramsci tinha bastante claro que o sucesso eleitoral poderia ser uma referência efêmera e ocasional, fruto de um boom, de uma explosão emotiva de pânico ou entusiasmo fictício. Todavia, não desconsiderava o valor sintomático das eleições como banco de prova da efetiva eficácia e capacidade de expansão e de persuasão de um determinado grupo social, e afirmava que a crítica de origem oligárquica ao regime parlamentarista e seu sistema eletivo onde o número é a lei suprema, baseava-se, na realidade, numa postura na qual "cada um é levado a confundir seu próprio 'particular' com o interesse natural", preferindo, assim, "se tornar elite por decreto" (GRAMSCI, 2002, p. 82). Gramsci (2002, p. 83) ressaltava ainda que tal crítica oligárquica ao regime parlamentarista acabara se estendendo a qualquer sistema representativo, mesmo não parlamentarista e não formado segundo os padrões da democracia formal, o que tornava estas afirmações oligárquicas ainda menos exatas, já que, nestes outros regimes:

o consenso não tem no momento do voto uma fase final, muito ao contrário. Supõe-se o consenso permanentemente ativo, a ponto de que aqueles que consentem poderiam ser considerados como 'funcionários' do Estado e as eleições como um modo de recrutamento voluntário de funcionários estatais de um certo tipo, que em certo sentido poderia vincular-se (em diversos planos) ao selfgovernment [autogoverno]. Já que as eleições se baseiam não em programas genéricos e vagos, mas de trabalho concreto imediato, quem consente empenha-se em fazer algo mais do que o cidadão legal comum para realizar tais programas, isto é, em ser uma vanguarda de trabalho ativo e responsável. O elemento ‘voluntariado' na iniciativa não poderia ser estimulado de outro modo para as mais amplas multidões; e, quando estas não são formadas de cidadãos amorfos, mas de elementos produtivos qualificados, é possível compreender a importância que pode ter a manifestação do voto.

Essa referência a um regime baseado num sistema representativo não parlamentarista e não formado segundo os padrões da democracia formal aponta para uma provável alusão gramsciana à experiência dos sovietes. Neste quadro, então, o consenso das massas deve ser a expressão orgânica de direção intelectual e moral, pela qual as massas se sentem permanentemente ligadas à ideologia e à liderança política do Estado como expressão de suas concessões e de suas aspirações. Como destaca Tamburrano (1965, p. 112), a realização da hegemonia socialista leva "à unificação cultural e moral e, portanto, política das massas, da grande maioria do povo que vive direta ou indiretamente explorado pelas relações capitalistas de produção ou de distribuição".

Para Cerroni (1965, p. 104), quando Gramsci esboça os traços característicos do novo Estado socialista, acentua sempre o conceito de autogoverno das massas justamente para destacar o fim do antagonismo entre direito público e privado, a progressiva reabsorção das funções políticas nas funções sociais. Além de permitir "uma conexão orgânica entre as relações de produção e as instituições político-jurídicas e esclarecer a realização prática da crítica teórica à sociedade dividida em classes", também permite reproduzir a distinção entre teoria marxista de Estado e as concepções que se aventuram ressurgir do seu aprofundamento, como a "teoria da violência" (e as variantes blanquistas e sorelianas) e o anarquismo - perspectivas estas "contra as quais os teóricos do marxismo se pronunciaram claramente" (CERRONI, 1965). Utilizando-se do exemplo do próprio Gramsci, pode-se afirmar que:

O modelo de Estado proletário não é a falsa democracia burguesa [...], mas sim a democracia proletária que realizará a liberdade das massas trabalhadoras; não é o parlamentarismo, mas sim o autogoverno das massas através de seus próprios organismos eletivos; não é a burocracia de carreira, mas sim os organismos administrativos criados pelas mesmas massas, com a participação real destas na administração do país e na construção da obra socialista (GRAMSCI apud CERRONI, 1965, p. 103).

É preciso evitar as equivocadas compreensões de que a superação do Estado capitalista, transformada em sociedade regulada, implicaria automaticamente na dissolução dos conflitos e num suposto fim da Política ${ }^{6}$. Gramsci mostra que no processo de dissolução do Estado burguês, a sociedade humana sofre um brusco processo de decomposição, e, mesmo vencido na luta de classes, o capitalismo deixará um resíduo impuro de fermentações estatais, onde indivíduos e grupos desejarão isentar-se das tarefas e da disciplina indispensáveis ao sucesso da revolução. A grandiosidade da revolução acarreta, então, na necessidade imediata de auto formação e de formação de um sentimento de responsabilidade rigoroso e implacável como a espada de um justiceiro, sob o qual a massa operária deve preparar-se efetivamente para a conquista do completo domínio de si mesma: 
Ao contrário do Estado burguês, que é tão mais forte no interior e no exterior quanto menos os cidadãos controlam e acompanham a atividade dos poderes, o Estado socialista exige a participação ativa e permanente dos companheiros na vida de suas instituições. Ademais, é preciso lembrar que o Estado é o instrumento para mudanças radicais e não se muda de Estado com a simplicidade com que se muda de governo (GRAMSCI, 2004, p. 256).

Dessa forma, a fundação do Estado proletário só será possível se a classe trabalhadora for capaz tanto de reconstruir a si mesma, quanto de dotar de significado e força política as instituições específicas da atividade própria dos produtores. Neste quadro, percebe-se que as instituições nascentes da atividade própria dos produtores tanto assumem o papel de organização econômica e política dos produtores, quanto se configuram como o fundamento do novo Estado, o que nos faz concluir que, para que o Estado proletário se realize como um Estado em que os produtores controlem também a organização da ordem não só econômica, mas também social e política, este Estado deverá, necessariamente, superar a típica divisão entre economia e política existente no Estado burguês.

\section{O caráter radicalmente democrático presente na essência da nova hegemonia anticapitalista das classes subalternas: a sociedade (auto)regulada.}

Percebe-se assim que, ao tornarem-se Estado, as classes subalternas não devem reproduzir as estruturas vigentes de poder e seus mecanismos de dominação, mas sim devem "reinventar uma nova maneira de fazer política e de viver em sociedade" (SEMERARO, 2001, p. 91). Todavia, sem uma clara percepção da contradição interna da sociedade civil e da ambivalência de sua relação com o Estado, corre-se o risco de que essa nova maneira de fazer política acabe atuando sempre à margem da política, sem perceber que a concepção de hegemonia supõe diferenças, multiplicidade, conflitos e interdependência entre partes sociais. Neste quadro, a expansão da sociedade civil, as dimensões da ética, da responsabilidade e a capacidade de autodeterminação da sociedade serão cada vez mais aprofundadas com o processo de transformação da estrutura que deverá ser realizado pela conquista da sociedade política por parte das classes trabalhadoras. Esta conquista deverá introduzir outra maneira de ser do homo oeconomicus, novas relações entre as pessoas e novos valores na sociedade ${ }^{7}$, e realizar a construção de uma sociedade socialista como sociedade realmente democrática, na qual o consenso das massas está assegurado para além das comprovações eleitorais e pela participação efetiva dos trabalhadores na vida dos organismos sociais e políticos, mas sobretudo pela unidade ideológica e cultural existente entre dirigentes e dirigidos e pela relação orgânica entre sociedade civil e sociedade política ${ }^{8}$. Este movimento criará as condições necessárias para a superação da atávica divisão, ou separação, entre dirigentes e dirigidos e para a instauração do autogoverno dos novos produtores que trabalham para a negação de toda e qualquer forma de domínio e pela extinção da alienação política. A sociedade auto regulada não se efetivará por uma artificiosa supressão da vida política, mas sim pela potencialização da mesma, ou seja, por um processo de admissão geral de todo o povo no exercício direto da soberania, tornada possível exatamente pelo processo econômico que, ao dissolver os alicerces da divisão de classe, abrirá necessariamente as portas à reabsorção do poder político na sociedade dos produtores.

O Estado não se limita a garantir as condições jurídico-formais entre as partes, mas determina também o monopólio da produção. A origem do poder político não depende de uma deliberada vontade de opressão da classe dominante, mas sim do processo histórico-econômico real, da substancial e estrutural característica do Estado como resultado necessário da divisão da sociedade em classes. A crítica do Estado não pode se esgotar na crítica da vontade da classe que o dinamiza, mas sim deve ser desenvolvida como crítica radical do processo de separação entre Estado e sociedade, entre política e vida econômica, entre estrutura e superestrutura. Um sistema hegemônico só consegue alcançar a universalidade, consistência e durabilidade se estiver sobre os pilares não apenas de um forte simbolismo ético-político, mas também de uma economia socialmente orientada. Implica a transformação da dinâmica interna do funcionamento da economia, de suas leis de funcionamento e de suas finalidades. Se qualquer modo de produção é também um modo de apropriação, a hegemonia da burguesia só pode ser destruída com a instauração de um novo modo de produção que permita a apropriação desalienante da realidade. Um programa de reforma econômica e uma modificação na posição social e no mundo econômico configuram-se como "o modo concreto através do qual se apresenta toda reforma intelectual e moral", e, consequentemente, através do qual "as camadas mais baixas logram uma elevação civil” (GRAMSCI, 2002, p. 19). Por outro lado, a concepção hegeliana do Estado ético "é própria de um período em que o desenvolvimento extensivo da burguesia podia parecer ilimitado e, portanto, a eticidade ou universalidade desta classe podia ser afirmada", na realidade, só o grupo social que propõe o fim do Estado e de si mesmo como objetivo a ser 
alcançado "pode criar um Estado ético, tendente a eliminar as divisões internas de dominados etc.; e a criar um organismo social unitário técnico-moral" (GRAMSCI, 2002, p. 285). A sociedade regulada não pode existir enquanto existir o Estado-classe, já que a sociedade regulada prescinde do fato de que a igualdade econômica é uma exigência fundamental para que se possa existir uma completa e perfeita igualdade política9 .

Nesse amplo quadro revela-se o caráter radicalmente democrático presente na essência da nova hegemonia anticapitalista das classes subalternas, caráter este que, superando os esquemas utilizados na teoria tradicional, não concebe a democracia limitada apenas ao plano político, mas sim também no campo das relações econômicas. Assim como em Marx, Engels e Lênin, os questionamentos de Gramsci alcançam a raiz última de onde deriva toda a divisão, a dominação e a violência que contaminam a trama das relações humanas e sociais, e, desta forma, acaba por imprimir ao conceito de democracia o sentido mais revolucionário elaborado na mais autêntica tradição marxista, pois esta democracia deve promover transformações profundas na estrutura e superestrutura e impulsionar a gradativa socialização do poder:

Entre os muitos significados de democracia, parece-me que o mais realista e concreto se possa deduzir em conexão com o conceito de hegemonia. No sistema hegemônico, existe democracia entre o grupo dirigente e os grupos dirigidos na medida em que o desenvolvimento da economia e, por conseguinte, a legislação que expressa este desenvolvimento favorecem a passagem molecular dos grupos dirigidos para o grupo dirigente (GRAMSCI, 2002, p. 287).

A única garantia real da passagem molecular das classes antes exploradas ao controle efetivo do poder, à conformação da hegemonia libertadora, é que esse novo modo de produção não se reduza a uma transformação de elementos quantitativos, a produção cada vez maior de máquinas e objetos de consumo, ou a potencialização do consumo dos bens materiais, mas que esteja centrado em uma capacidade de alcançar a socialização da propriedade e introduzir a democracia econômica. Contrariamente às posições assumidas até então pelas classes dominantes, as quais estabelecem uma hegemonia que se alicerça sobre um consenso manipulatório e uma articulação forçada, a hegemonia construída pelas classes subalternas é mais do que uma estratégia de luta, é uma nova categoria de interpretação da realidade, que tem como cimento não o consenso passivo e indireto, mas o consenso ativo e direto, ou seja, é um movimento que permite a participação política e a transformação moral e intelectual dos indivíduos (GRAMSCI, 2002).

\section{Gramsci afirma a}

construção de uma verdadeira

democracia radical, na qual as

classes subalternas são

elevadas à condição de

protagonistas, dirigentes e

responsáveis da sua própria

história...

A rejeição de toda estruturação do campo e das práticas políticas que se assentam na dupla separação públicoprivado e produção-reprodução faz com que a reinterpretação gramsciana da democracia, no contexto de sua formulação do conceito da hegemonia, represente uma decisiva ruptura em relação às formas tradicionais de compreensão e realização da política efetuadas pela esquerda até então. Ao determinar que "toda relação de 'hegemonia' é necessariamente uma relação pedagógica", existente "em toda a sociedade no seu conjunto e em todo indivíduo com relação aos outros indivíduos, entre camadas intelectuais e não intelectuais, entre governantes e governados, entre elites e seguidores, entre dirigentes e dirigidos" (GRAMSCI, 2002, p. 399), e ao indicar que é através dessa hegemonia que as classes subalternas acolhem as novas culturas, articulam as novas sensibilidades e promovem nova organização socioeconômica, Gramsci afirma a construção de uma verdadeira democracia radical, na qual as classes subalternas são elevadas à condição de protagonistas, dirigentes e responsáveis da sua própria história, tornam-se pessoas históricas, pois deixam de ser resistentes a uma vontade estranha para se tornarem agentes e necessariamente ativos (GRAMSCI, 2002).

\section{Referências}

BADALONI, N. Il marxismo di Gramsci - dal mito alla ricompasizione política. Turim: Einaudi, 1975.

CERRONI, U. Gramsci y la superación de la separación entre sociedad y Estado. In: TOGLIATTI, P. et al. Gramsci y el marxismo. Buenos Aires: Editorial Proteo, 1965. p. 97-106. 
COUTINHO, C. N. Gramsci: um estudo sobre seu pensamento político. Rio de Janeiro: Campus, 1999.

CRESS. Conselho Regional de Serviço Social - 7a região. Orientação Profissional: Informações básicas para o assistente social. Rio de Janeiro, 2008.

GRAMSCI, A. Cadernos do Cárcere. Rio de Janeiro: Civilização Brasileira, 2002. 6 v.

Escritos políticos. Rio de Janeiro: Civilização Brasileira, 2004. 2 v.

GUEVARA, E. C. Socialismo e juventude. São Paulo: Anita Garibaldi, 2005.

HEGEL, G. W. F. Princípios da filosofia do direito. São Paulo: Martins Fontes, 1997.

LIGUORI, G. Roteiros para Gramsci. Rio de Janeiro: Editora UFRJ, 2007.

SEMERARO, G. Gramsci e a sociedade civil: Cultura e educação para a democracia. Petrópolis, RJ: Vozes, 2001a.

TAMBURRANO, G. Gramsci y la hegemonía del proletariado. In: TOGLIATTI, P. et al. Gramsci y el marxismo. Buenos Aires: Editorial Proteo, 1965. p. 107-116.

WOOD, E. M. Democracia contra Capitalismo: a renovação do materialismo histórico. São Paulo: Boitempo, 2003.

\section{Notas}

1 Sobre o termo democracia política, o desenvolvimento da democracia moderna se mostrou compatível com o desenvolvimento do capitalismo na medida em que a burguesia conseguiu neutralizar as implicações econômico-sociais da democracia a ponto de mantê-la no plano estritamente político, cujos instrumentos, apesar de terem propiciado à classe trabalhadora, por meio de suas lutas, uma série de conquistas que tocaram nas próprias condições do desenvolvimento econômico, não atingiram o cerne das condições estruturais da ordem burguesa (propriedade privada dos meios de produção, mercantilização da força-de-trabalho e extração de mais-valia). Se a ideia de democracia como igualdade implicava a subversão da ordem burguesa, sua tradução através de mecanismos de liberdades jurídicas e constitucionais permitiu a inserção desta demanda nos princípios básicos do pensamento liberal, reduzindo a sua reivindicação à divisa estritamente política (WOOD, 2003).

2 Pois não tendiam a assimilar organicamente as outras classes, ou seja, a ampliar técnica e ideologicamente sua esfera de classe.

3 'Dá-se o nome de 'estatolatria' a uma determinada atitude em relação ao 'governo dos funcionários' ou sociedade política, que, na linguagem comum, é a forma de vida estatal a que se dá o nome de Estado e que vulgarmente é entendida como todo o Estado" (GRAMSCI, 2002, p. 279).

4 "O conceito de Estado ético é de origem filosófica e intelectual (própria dos intelectuais: Hegel)" (GRAMSCI, 2002, p. 85).

5 "Que se lute para destruir um conformismo autoritário, tornado retrógrado e embaraçoso, e se chegue ao homem coletivo através de uma fase de desenvolvimento da individualidade e da personalidade críticaé uma concepção dialética difícil de ser compreendida pelas mentalidades esquemáticas e abstratas. Assim como é difícil compreender que se sustente que através da destruição de uma máquina estatal se chegue a criar uma outra, mais forte e complexa etc." (GRAMSCI, 2002, p. 289).

6 Tais compreensões desconsideram, ou não percebem, que, no seu empenho em afirmar o papel criador da práxis humana, Gramsci foi levado a privilegiar o estudo do fenômeno político em suas várias determinações, empregando ao conceito de política duas acepções fundamentais as quais podem ser denominadas de ampla e restrita. No seu sentido amplo, a política é sinônimo de catarse, de passagem do momento objetivo ao subjetivo, da particularidade à universalidade, da necessidade à liberdade; ou seja, é uma determinação ineliminável da práxis humana, da própria estrutura ontológica do ser social, identificada com todas as formas de práxis que superam a simples recepção passiva ou a manipulação dos dados imediatos da realidade. Na sua acepção restrita, a políticaé algo historicamente transitório, que será dialeticamente superado no comunismo, tendo em vista que envolve o conjunto das práticas e das objetivações diretamente ligadas às relações de poder entre governantes e governados, e que recebe uma importante distinção categorial na contraposição gramsciana entre grande política, ou alta política, e pequena política, a política do diaa-dia, política parlamentar, de corredor, de intrigas: “A grande política compreende as questões ligadas à fundação de novos Estados à luta pela destruição, pela defesa, pela conservação de determinadas estruturas orgânicas econômico-sociais. A pequena política compreende as questões parciais e cotidianas que se apresentam no interior de uma estrutura já estabelecida em decorrência de lutas pela predominância entre as diversas frações de uma mesma classe política. Portanto, é grande política tentar excluir a grande política do âmbito interno da vida estatal e reduzir tudo a pequena política. [...] Ao contrário, é coisa de diletantes pôr as questões de modo tal que cada elemento de pequena política deva necessariamente tornar-se questão de grande política, de reorganização radical do Estado" (GRAMSCI, 2002, p. 21-22).

7 Na teoria social contemporânea existem importantes críticas internas ao marxismo questionando uma concepção de que o fim das relações capitalistas e suas contradições traria também, automaticamente, o fim dos diferentes tipos de opressão e preconceitos que interferem nas relações de gênero, nas questões étnico-raciais etc. A construção do socialismo não pode avançar somente pelas transformações no modo de produção, na base econômica, mas deve trazer com ela, também a construção do homem novo, compreendendo que o ser social transforma a si mesmo ao mesmo tempo em que opera a transformação da sociedade. Conforme nos esclarece Guevara (2005, p. 50-51), as marcas do passado serão transmitidas na consciência individual do presente, trazendo a necessidade de se fazer um trabalho contínuo para erradicá-las: "é necessário que se desenvolva uma consciência na qual os valores adquiram categorias novas. A sociedade em seu conjunto deve transformar-se em uma gigantesca escola".

8 Cabe destacar a discordância de Gramsci com os realistas políticos, os quais recusam o argumento de que o consenso é pressuposto da estabilidade política e consideram que o conflito pode ser eliminado apenas na prática, e não em princípio: 'O 'excessivo' (e, portanto, superficial e mecânico) realismo político leva muitas vezes à afirmação de que o homem de Estado só deve atuar no âmbito da 'realidade efetiva', não se interessar pelo 'dever ser', mas apenas pelo 'ser'. Isto significa que o homem de Estado não deve ter perspectiva para além do tamanho de seu nariz” (GRAMSCI, 2002, p. 34). 
9 "A confusão entre Estado-classe e sociedade regulada é própria das classes médias e dos pequenos intelectuais, que se sentiriam felizes com uma regulação qualquer que impedisse as lutas agudas e as catástrofes: é condição tipicamente reacionária e retrógrada” (GRAMSCI, 2002, p. 224).

\section{Douglas Ribeiro Barboza}

douglasrb@id.uff.br

Doutor em Serviço Social pela Universidade Federal Fluminense (UFF).

Professor da Escola de Serviço Social da Universidade Federal Fluminense (UFF)

\section{Jacqueline Aline Botelho Lima Barboza}

jbotelho@id.uff.br

Doutora em Serviço Social pela Universidade Federal Fluminense (UFF).

Professora da Escola de Serviço Social da Universidade Federal Fluminense (UFF).

\section{UFF}

Rua: Professor Marcos Waldemar de Freitas Reis, S/N. Campus do Gragoatá - Bloco E

São Domingos

Niterói - Rio de Janeiro - Brasil

CEP: 24210-201 